\title{
The Relation between Christianity and Colonialism in Ngugi Wa Thiong'o's The River Between
}

\author{
Tatang Iskarna \\ tatang.iskarna@gmail.com \\ Department of English Letters, Universitas Sanata Dharma
}

\begin{abstract}
This article is aimed at describing how the relation between Christianity and colonialism is constructed in The River Between (1965), a novel by Ngugi wa Thiong'o. Using postcolonial approach focusing on the analysis of the characters and conflicts, this study reveals the mutual relation between Christianity and colonialism. Christianity becomes the ideological apparatus to build a colonial myth, doctrine, or perspective, while Christian missionaries gain the colonizers' support from the colonial administrators. Their antagonistic relation can be explored through the natives' re-reading of the Bible to review the colonialism and get rid of the colonial bondage. As postcolonial literature, The River Between offers counter-discourse against colonialism. However, some parts of the text are still slipped in the colonial hegemony.
\end{abstract}

Keywords: Christianity, colonialism, postcolonialism, ideological apparatus, counter-discourse

\section{Introduction}

Amongst historians, anthropologists, culture researchers, or missionaries there is a debate on whether or not Christianity has relation with colonialism. There are some perspectives on this debated relation. Christianity in some colonial cases is viewed as the religious arm of colonialism because both of them have almost the same mission which works side by side, that is to improve the nonEuropean world. Missionaries change the pagan or heathen into Christian convert, while colonizers alter the primitive into the civilized (Bevan, 2016 para. 2). However, Christianity cannot be associated with colonialism because Christianity actually has existed for centuries before European colonialism emerged. Besides, the interaction between Christian missionaries and the colonized people is not influenced by geographical or ethnical factors. It is not similar to the rational Europeans' mission to civilize the primitive Africans or Asians. Missionaries do not have anything to do with the worldly ambition of power as the colonizers do. Christianity spreading is purely the commandment of God as written in the Bible (Sidjabat, 1964:24)

In some colonized African countries Christianity is supposed to be the religion of the colonizer. It is associated with oppression and violence (Arntsen, 1997, para.3) as it is portrayed in African literary works, such as Achebe's Arrow of God (1964), Thiongo's's The River Between (1965), or p'Bitek's Song of Lawino (1966). However, it is also viewed as the religion of solution. Schools, health clinics, and churches founded by the Christian missionaries are the centre for improving the life of the native and colonized African people. In some English literary texts, the Africans are often described as the unengaged and uncivilized people group. They are presented as primitive, immoral, irrational, and superstitious heathens who need to be civilized and educated (Guth, 1981:549; Kohn, 2012 para.2). These texts unconsciously often 
develop colonial discourse that the civilizing project is the glorious burden that the European people do to the rest of the world, especially Africa. The English literary works, such as Defoe's Robinson Crusoe (1719), Conrad's Heart of Darkness (1899), Kippling's South Africa (1903), Green's Journey without Maps (1936), or Cary's Mister Johnson (1939) reinforce this colonial discourse.

Along with the rise of the consciousness of the colonial oppression and the national movement of resistance against the colonialism, some African writers produce counter-discourse literary works which in some ways encourage the readers to resist the hegemonic colonial discourse built by the Europeans. African writers, such as Chinua Achebe, Wole Soyinka, Nadine Gordimer, J.M. Coetzee, Ngugi wa Thiongo's, and Okot p'Bitek, in their works present Christianity in cooperation with colonialism as the projects that actually do not bring improvement but destruction. The encounter between the Christian European and traditional African culture brings about some problems, such the vanishing of the African native culture, racism, exploitation, and unequal relation, that is domination and subordination (Khapoya, 2012:125).

African people have various experience when they have relation with the European colonialism. So, it is such a worth discussing to study one of the African literary texts, that is The River Between (1965) written by Ngugi wa Thiongo's, to probe the relation between Christianity and colonialism. This study will enrich the readers' perspective in understanding the relation between Christianity and colonialism from the African writer's view. In order to get the study focus, the following questions are going to be answered. The first is "What is the relation between Christianity and colonialism as constructed in The River Between?", and the second is "How is The River Between viewed as a postcolonial novel offering counterdiscourse against colonialism through this relation?

\section{Christianity from Colonial and Postcolonial Perspectives}

To answer the above questions, it is necessary to review what Christianity is and how it is viewed from postcolonial perspective. Besides, colonialism must be also discussed from two perspectives, colonial and postcolonial. Christianity can be essentially and theologically a belief and spirituality and politically an ideology. Colonialism in Europeans' perspective can be a civilizing project to improve the life of the primitive world and the act of exploitation and domination of people group's territories by others.

Generally most dictionaries define Christianity as a religious belief based on the life and teaching of Jesus Christ. Five Gospels and the Book of Acts declare that this belief is first embraced by the Jewish people and some gentiles in Jerusalem who believe that Jesus Christ was the real Messiah who saves the human beings falling into sin. It is then spread to Asia, and Europe. From Europe, Christianity is spread to the end of the world. According to Thiessens, Christianity is based on some principles. The first is that human beings must believe in the one God Almighty, the creator of human being and the universe (1997:113). The second is that human beings fall into sin and need salvation (1997:231). The third is that the salvation is gained from Jesus Christ who died on the cross and shed his blood as the substitution of sacrifice to punish the sinful human beings (1997:303). God founds a church, the fellowship of Christian believers, through which $\mathrm{He}$ gives providence and commands to preach the Gospel and to make all nations Jesus' disciples with the power of the Holy Spirit (1997:473). The fourth is that the Bible is the word of God and used as the orientation of Christian life (1997:65), and there is the resurrection of the body, eternal punishment, and eternal life (519).

Christianity has a missionary duty. This duty is to spread the Gospel of salvation and to make the nations Jesus' disciples. It is marked by the project of evangelism. Jesus sent his disciples, and his disciples sent to other disciples from one generation to the next to spread the good news of the salvation in Jesus 
(Peters, 2006:39). Every Christian has responsibility of preaching the Gospel to every human being (Schnabel, 1967:451). This mandate is clearly declared in the book of Matthew 28:19-20, Mark 16:15, and Acts 4:31. As a missionary belief, Christianity develops from Jerusalem, Syria, Turkey, Greece, Italy, and most parts of Europe. From Europe, it spread to Asia, Africa, Australia, and America (Schnabel, 1967:33-110).

The evangelism continues in the era of colonialism. Conversion from heathen to a monotheist is the important element of civilizing the colonized people. This conversion project is called civilizing mission (Kohn, 2012, para.2, Khapoya, 2012:106-107). Christianity becomes the civilizing force during the colonialism project (Guth, 1981:549). Christianity is used to teach the colonized Africans to submit themselves to the Europeans as they are considered as the heathen needed to be converted. Embracing traditional belief and values is similar to sinful behaviour. All their norms and habits should fit the Christianity and European culture. Christianity tends to be the belief which promotes oppression and political tyranny (Arntsen, 1997, para.7). Christianity becomes one of the European cultures. It is not a religious belief, rather it is a part of colonial structure. Jesus, as Wolf Schmidt S.J. states, is forced to be the European white, in fact He is not (Arntsen, 1997, para.4).

In the hands of the colonizers, Christianity is employed as theological reference to reinforce the polarization the civilized European society and the native African people (Said, 1978:12). Orientalism, a colonial view of how to define non-European as uncivilized, irrational, and exotic heathen in binary comparison with the European as civilized, rational, and modern believers (Said, 1978:18), is actually a secular discourse which originally derives from Christianity. The binary opposition between the European and non-European is maintained and is used as religious discourse of the believer and the heathen which is reconstructed repeatedly. Orientalism is a modern discourse of Christianity (Said, 1978:121-122).

\section{The Relation between Christianity and Colonialism}

Some missionaries believe that colonialism project is almost the same as the evangelism. Colonialism, as Jan H. Boer states, is a divine mandate organized and planned to free the colonized from the spiritual and social-economic bondage (Falola, 2001:33). Christianity and colonialism should be one package, that is missionaries convert the colonized and colonizers civilize the colonized (Gray, 1982:71). Christian missionaries provide schools, hospitals, and church to form a colonial perspective so that the colonized people can be submissive. It is such an indirect method of domination (Ashcroft et.al, 2007:127). Christianity can be used as an ideological instrument to build a myth, perspective, or doctrine that make colonized people submit to the colonial power (Loomba, 2005:32-33). Althusser (2001:1484) also states that religion can be the ideological apparatus to dominate other people. Ideological apparatus represents imaginary inter-individual or inter-group relation which is drawn to the real condition. This imaginary relation is built to control other people. The example proposed by Althusser is the domination of a Christian priest to his congregation on behalf of the teaching of Christianity as the ideology.

For the colonizers, the Bible can be a strategic tool of colonizing the native people. It can be used to expose the sin of the primitive heathens. As they are sinners and heathens, they deserve to receive violence and oppression as the representation of the punishment of their sins. The arrival of the Bible's teaching replaces the native rules and norms, so the local and traditional artefacts of the colonized people are nothing more than superstition. Moreover, they are not considered authentic (Surghitarajah, 2005:6263).

Christianity takes advantage of colonialism. Colonial administrators, traders, and military contribute and provide fund and protection to the Christian missionaries. The colonial government also builds infrastructure, especially road access to the remote area of the Africans. Colonialism 
becomes the vital element of Christianity (Okon, 2014:199).

However, Bible can be used by the colonized to resist against colonialism. The spiritual idea in the Bible is applied practically and adjusted critically to the local values. For example, the story of the slavery of Israelites in Egypt can become the starting point to resist against colonialism (Surghitarajah, 2004:7576). Christianity can also be used by the colonized as a tool of social and economic access. Adopting Christianity is not being a pure and faithful Christian but gaining access to the colonial superiority and modernity (Berkhof, 2014:367). "It became fashionable to be called a Christian ... All new ideas including Christianity are acceptable when the Africans see that they are obviously useful (Ekechi, 1971:104)

\section{Discussion}

\section{The Relation between Christianity and Colonialism in The River Between}

The River Between tells a story of Kikuyu people who live in Makuyu and Kameno hills. The two societies are separated by a river named Honia. Having been influenced by the arrival of the British colonizers, Makuyu people adopt British culture including Christianity. Joshua lead the Makuyu people and become the Kikuyu Christian priest who always urges the Kikuyu people to embrace Christianity and leave their traditional belief because it is a kind of sinful ritual. Kameno people still maintain the traditional values and belief. They worship some gods who protect the village. Chege, the Kameno chief, and his son, Waiyaki, struggle to free the Kikuyu from the colonial bondage. However, Chege sends Waiyaki, the Kameno prospective leader, to Christian mission school for the purpose of learning the strategy of the British colonizers in dominating the native land. On the way of his study, Waiyaki admits the importance of adopting British education and appreciate Christianity as it teaches good things. Waiyaki founds a school for the native Kenyan after most of the Kenyan students are cast out from the mission school because of their parents' practice of traditional circumcision. The story ends tragically when Waiyaki is punished by the traditional custom council because of his love relationship with a Christian Kikuyu girl from Makuyu and his interest in British education.

The mutual relation between Christianity and colonialism can be observed through the characters of British colonizers and the local and British Christian missionaries in interacting with the native Kenyans. After the invasion of the British military and the founding of the colonial administrative centre, Siriana mission is built. Around the administrative centre, missionaries also build churches, health clinics, and mission school. The schools and health clinics become the effective place to introduce Christianity to the native Kikuyu before finally they embrace Christianity and worship God in churches. The missionaries make many Kikuyu Christian disciples. One of them is Joshua, a Kikuyu native who lives in Makuyu. Only in short time, most of Kikuyu people in Makuyu embrace Christianity.

Joshua is the first person who dedicates and submits to Christianity under the supervision of Livingstone, a British missionary. He declares that he has found a real God which is the God of Christian people and quit his traditional belief:

In Siriana he (Joshua) found sanctuary and the white man's power and magic. He learnt to read and write. The new faith worked in him till it came to possess him wholly. He renounced his tribe's magic, power, and ritual. He turned to and felt the deep presence of the one God (Thiong'o, 1965:29)

Joshua also tells Kikuyu people that Jesus is the real saviour as prophesied by many prophets, one of whom is Isaiah, hundred years before Jesus was born. Joshua becomes the fundamental Christian whom can be used effectively by the missionary to introduce Christianity to Kikuyu people. He states that those who reject Jesus can be called children of darkness and go to hell: 
Isaiah, the white man's seer, had prophesied of Jesus. He had told of the coming of a messiah. Had Mugo wa Kibiro, the Kikuyu seer, ever foretold of suc a saviour? No. Isaiah was great. He had told of Jesus, the saviour of the world. Those who refuse Him are the children of darkness; these sons and daughters of the evil one, will go to hell; they will burn and burn for ever more, world unending (Thiong'o, 1965:29).

Joshua's teaching spreads in the Makuyu lands. Many Kikuyu people are converted to Christianity and leave behind their traditional religion. This binary opposition built by the missionary and Joshua that Christianity worships real and living God and Kikuyu traditional religion teaches to worship Satan become the starting point for the missionary and colonizers to make the Kikuyu people internalize the British culture and submit to the colonial power. In this case, Christianity becomes the ideological apparatus (Althussers, 2001: 1484; Loomba, 2005:3233 ) to build myths, doctrines, or perspectives to conquer the Kikuyu people to submit to the British colonial rulers.

The important doctrine which is prominently taught to the Kikuyu people is about how to respect and submit to the government, in this case British colonial rulers. Joshua advises the Kikuyu people to what the British ruler orders to do for the sake of the obeying the God and His words in the Bible. When some Kikuyu people reject to pay tax and work as a colonial plantation labour, Joshua commit to support the British policy:

Joshua did not mind this (the tax). He himself knew what a government was, having learnt about this from Livingstone. He knew it was his duty as a Christian to obey the Government, giving unto Caesar the thing that are Caesar's and to God the things that are God's. That was what he wanted every Christian to do. And was the white man not his brother? (Thiong'o, 1965:33)

In church, Joshua always preaches the bad condition of the Kikuyu people who still believe in false gods of darkness. Joshua quotes some verses which are given to Israelites who leave God Almighty to describe the situation of the Kikuyu people:

For all have sinned and come sort of the glory of God (Thiong'0, 1965:84)

\begin{abstract}
"Hath a nation changed their gods which yet were no gods? But my people have changed their glory for that which doth not profit" (Thiong'0, 1965:85).
\end{abstract}

For this reason, Joshua invites Kikuyu people to come to church and worship the real and true God, God who is worshipped by the British people and to ignore the old traditional way of worshipping false gods:

Therefore, brothers and sisters, I tell you today, come to Jesus. Stand by Him...Remember life here on earth is one of trials and of hardship. Satan will come to you at night, in your own house, in your field, or even in church here, and he will whisper to you calling back to the old ways (Thiong'o, 1965:85).

Joshua asks the Kikuyu people that they should not compromise with the old belief. As a Christian he will not stand in two sides between Christianity and pagan because Jesus has given His life to redeem the human beings by hanging on the cross with full commitment and sacrifice:

My brothers and sisters, there is no
compromise. Our Lord did not
compromise when he hung on the cross.
He did not mix two ways but stood by the
Light. (Thiong'0, 1965:86)

Christianity as ideological apparatus through education has an important role to quieten Kikuyu people in order that they do not resist and rebel when their lands are invaded and dominated. This can be analyzed through the characters of Waiyaki who is sent to Siriana mission schools:

For Waiyaki was a greater menace than the people realized. He was in league with the white man, who had brought a secret religion to quieten the people while the 
land was being grabbed by their brothers (Thiong'o, 1965:147)

Joshua also convinces Kikuyu people that there are some rituals that should be banished from Makuyu and Kameno, one of which is traditional circumcision. Joshua thinks that this ritual is from Satan and not in accordance with the teaching of Christianity. Joshua's proposition about the danger of circumcision comes true when his own daughter who experiences circumcision as the sign of her being adult dies because of the infection from the circumcision. Joshua associates the circumcision ritual with the devil's work:

To him Muthoni had ceased to exist on the very day that she had sold herself to the devil. Muthoni had turned her head and longed for the cursed land. Lot's wife had done the same thing and she had been turned to stone, a rock of salt, to be forever a stern warning to others. (Thiong'o, 1965:54)

The other mutual relation between Christianity and colonialism can be detected through the infrastructure building, such as road or railways as the access to spread the Gospel to the remote areas in Kenya:

"See them, the butterflies"..."They are there beyond the ridges, putting up many houses and some taking the land"..."Nairobi was already flourishing, and the railway was moving across the country in the land beyond where not many from the ridges had been. The white man cannot speak the language of the hills and knows not the ways of the land. But the white man had come to Siriana, and Joshua and Kabonyi had been converted. They had abandoned the ways of the ridges and followed the new faith" (Thiong'0: 1965:7)

When the Kikuyu lands are dominated and conquered, the British colonial administration build a post with its rules and culture. The administrative post usually is accompanied by Christian mission with its schools, clinics, and churches. The missionaries are protected with British colonial administration and military:

For the whole of that year things had not gone well with Joshua. People at Kameno were becoming restless and believed that it was Joshua who responsible for the white men who these days come to the hills. There were rumours that a Government Post would soon be built at Makuyu and that the hills would be ruled from there (Thiong'o 1965:31).

Christianity in the above cases can be used as a cultural tool to conquer the native Kikuyu people. However, Christianity can also be used as the base of the critical thinking against colonialism. The education that Waiyaki takes makes him aware of and sensitive to the oppression imposed by the British colonizers. Waiyaki's interpretation on the Bible teaching makes him aware that he should not hate Christianity but the colonial behaviour of the British people:

To Waiyaki the white man's education was an instrument of enlightenment and advances if only it could be used well....Learn all the wisdom and all the secrets of the white man, but do not follow his vice (Thiong'o, 1966:119).

To Waiyaki, Christianity is not false religion. Many truths of this belief can be applied and be beneficial to the Kikuyu people. Christianity should be re-interpreted and its colonial hermeneutic of this teaching needs to be evaluated. All the wicked interpretation should be abolished:

For Waiyaki knew that not all the ways of the white man were bad. Even his religion was not essentially bad. Some good, some truth shone through. But the religion, the faith need washing, cleaning away all the dirt, leaving only the eternal (Thiong'o, 1966:119).

Chege, Waiyaki's father, also suggest that Waiyaki should learn the good and beneficial things from Christianity but doest not have to follow the British people conduct. Christianity should change Waiyaki's attitude 
to give more love and commitment to his Kikuyu people:

Go to the Mission place. Learn all the wisdom and all the secrets of the white man. But do not follow his vices. Be true to your people and the ancient rites (Thiong'o, 1965:20)

Having been educated in Christian mission school, Waiyaki is aware of the condition of his people. Kikuyu people are oppressed and should be set free from the colonial bondage. Education from Christian school is the way to solve this problem. This education will make people aware of their condition. The solution offered by Waiyaki is that the Kikuyu people should be independent, build their own school, and have their own native teachers. Christian teaching also contains how people should love each other and be set free from the bondage.

\section{The River Between as the Postcolonial Literature}

In some books on literary theories and practice, The River Between is classified as a postcolonial novel, in the way that this writing presents and gives critical reviews on the relation of the colonized and colonizers with its complicated relation (Boehmer, 2005:5). This novel also reveals the local reading and views on the arrival of British colonizers and missionaries which is different from the European centre (Ashcroft, 2002:2) in the way that the arrival of Christianity and colonialism bring about some social problems amongst the African natives. This work has strong relation with the national movement of African freedom and nationalism (Innes, 1990:1131). The rise of the local culture, social change, and local conflict caused by the European encounter (King, 1990:1114-1115) becomes the prominent characteristic of this novel.

As postcolonial literature The River Between offers the counter-discourse reading of the British civilizing mission of colonialism and conversion project of the British missionaries. The arrival of colonialism is not viewed only as the civilizing force but also perceived from the perspective of racism and exploitation which is attached to it (Makaryk,
1993:155-156). Analyzed from the postcolonial view, the construction of the Christianity and colonialism told in this novel shows the plural and different comprehension and change in paradigm (Barry, 2002:199) amongst the Africans. This novel also describes some traces of the relation between the colonized and colonizers and its huge social impact (Foulcher and Day, 2008:3). Finally, the operation of the colonial hegemony can be detected through the close reading of the novel (Faruk, 2007:17) even though this novel is classified as anti-colonial novel.

The River Between shows the colonialism as the representation of racism and a proof of how Africans are described negatively as primitive and inferior pagan (Fanon, 1967:810). The relation between the colonized Kikuyu and British colonizers is nothing more than the relation of oppression, intimidation, and exploitation (Cesaire, 1972:6). In this novel it can be observed how the British colonizers build a discourse in which the Kikuyu people are described as a lazy, poor, stupid, and savaged group of people (Memmi, 1965:71).

This novel presents Christianity as a religious belief which applies binary opposition view on the African native and its traditional belief. Christianity is considered to be the light and the Kenyan traditional belief with its false gods to be the darkness as it is expressed by Joshua:

He (Joshua) realized the ignorance of his
people. He felt the depth of the darkness in
which they lived. He saw the muddy water
through which they waded unaware of
the dirt and the mud. His people
worshipped Marungu, Mwenenyaga,
Ngai. The unerring white man had called
the Kikuyu god the prince of darkness
(Thiong'o, 1965:29)

Christian view is so strict that the local ritual such as circumcision as the sign for the maturity of Kikuyu people is not tolerated. Joshua has told his daughter, Nyambura, on this matter. It is a kind of pagan habit:

For Nyambura had learnt and knew that circumcision was sinful. It was pagan rite 
from which she and her sister had been saved. A daughter of God should never let even a thought of circumcision come to her mind. Girls of their age would be initiated this season. Had her father, Joshua, not been a man of God, he, no doubt, would have presented them both as candidates (Thiong'0, 1965:23).

In church and his preach Joshua always tells Kikuyu people that this traditional ritual is satanic and sinful:

And Joshua's followers gathered. They talked and sang praises to God. Muthoni was an evil spirit sent to try the faithful. It was clear to all that nothing but evil could come out of adherence to tribal customs. Circumcision was whole evil (Thiong'o, 1965:58)

Beside its binary opposition view, the coming of the Christianity brings about social problems. Kikuyu people are divided into two groups, the one who live in Makuyu and the one who live in Kameno. These two societies are separated by Honia river. The clan and family bond is cut off and broken by this new religion. Joshua as the Christian fanatic is willing to cast away her daughter Muthoni who involves in traditional circumcision ritual. When Muthoni dies from the infection, Joshua does not show his sorrow emotion. He even is angry with Muthoni's decision and considers her as the devil's child:

Joshua heard of the death of Muthoni without a sign of emotion on the face. To him, Muthoni had ceased to exist on the very day that she had sold herself to the devil (Thiong'o, 1965:53).

Most of the traditional customs in Kikuyu lands vanish since the arrival of Christianity. The destructive effect of this new religion on the local culture can be felt by Kikuyu people. The worship of the ancestors is removed, the ritual of the traditional succession is replaced by the church, or the respect to the elders is not practiced anymore as the leadership is in the hand of the Christian priest, not the tribal chief.
However, this novel reveals the positive impact of the arrival of Christianity. Christian education in mission school becomes the model of civilizing the Kikuyu and the starting point of the awareness of their oppression. Education can be used as a tool to unite all tribes in Kikuyu lands. It is not the oppressive British people's behaviour that the Kikuyu people pay much attention to but its Christian teaching.

The ending of the story also shows the ambivalence of the anti-colonial attitude of the novel. The main character or the hero, in this case Waiyaki, must be banished from the Kikuyu land by the Kikuyu custom council. He is not allowed to develop the education amongst the Kikuyu people. He is punished because of his relationship with Christian Kenyan girl and his attitude which is viewed as a betrayal toward the Kikuyu culture. On the one hand, this novel gives critical view on the colonialism and Christianity, on the other hand it seems to take side on the Christianity. It is possible that colonial hegemony still operates side by side with the discourse of anticolonialism.

\section{Conclusion}

The River Between is a novel which contains the construction of the relation between Christianity and colonialism. From postcolonial view, this novel shows how Christianity is used as the ideological apparatus to build a myth, doctrine, and perspective to make the colonized Kikuyu people submit to the colonial power. In response, British colonial administrator provides support to the Christian missionaries.

Native evangelists and local Christian preachers who have internalized Christianity are used to convince their people to leave behind their traditional religion and customs because they are associated with the devils. Bible is interpreted in such a way that obeying the colonial government is advised for native Christians. Colonial hermeneutic of the Bible becomes the base of the relation between Christianity and colonialism. The British colonial administrators build roads and railways to access the remote countries which are not yet engaged by the missionaries. 
Security and protection are given to the Christian missions. Funding and land are also provided.

However, the awareness of the independence movement from the colonial bondage derives from the Christian education. Waiyaki, the hero of this novel, encourages the Kikuyu people to view critically the British colonialism and solve the social problems concerning with the undeveloped lands of Kikuyu and the broken inter-group relation using education he gets from mission school. The key to solve the social and economic problem of the native Kikuyu is the education. Using local hermeneutic of the Bible, Waiyaki initiates to respect the Christianity but ignores the oppressive behaviour of the British colonizers.

The River Between offers counterdiscourse against colonial hegemony through the representation of the British oppression to the native Kikuyu. Besides, the arrival of the Christianity becomes the source of broken relation amongst the families, clans, and neighbours of Kikuyu people. However, in this novel it is Christianity and its education which play significant roles in making the colonized Kikuyu aware of their condition and problems. It indicates that the colonial hegemony is not at all rejected and resisted.

\section{References}

Althusser, Louis Pierre. "Ideological Apparatus State", The Norton Anthology of Theory and Criticism, Ed. Vincent B. Leitch, New York: W.W. Norton and Company, 2001.

Ashcroft, Bill, Gareth Griffiths, and Helen Tiffin. TheEmpire Writes Back: Theory and Practice in Postcolonial Literature, London: Routledge, 2002.

Barry, Peter. Beginning Theory: An Introduction to Literary and Cultural Theory. Manchester: Manchester University Press, 2002.
Berkhof, H. Sejarah Gereja. Jakarta: BPK Gunung Mulia, 2014.

Bevans, Stephan, "New Evangelical and Mission". Divine Word Missionary Magazine. Summer, 16 Septermber 2016.

Web.http://www.secondenlightenment. org/Christian \%20Complicity.pdf

Bohmer, Elleke. Colonial and Postcolonial Literature. Oxford: Oxford University Press, 2005.

Cesaire, Aime. Discourse on Colonialism. Transl. Joan Pinkham. New York: Monthly Review Press, 1972.

Falola, Toyin. Violence in Nigeria: The Crisis of Religious Politics and Secular Ideologies. New York: University Rochester Press, 2001.

Fanon, Frantz. Black Skin, White Masks, Ed. 10, Transl. Charles Lam Markmann, London: Pluto Press, 1967.

Faruk. Belenggu Pascakolonial: Hegemoni dan Resistensi dalam Sastra Indonesia. Yogyakarta: Pustaka Pelajar, 2007.

Foulcher, Keith and Tony Day. Ed. Sastra Indonesia Modern: Kritik Poskolonial. Jakarta: Yayasan Obor, 2008.

Gray, Richard. "Christianity, Colonialism, and Communications in Subsaharan Africa", Journal of Black Studies. Vol. 13, No.1, 1982: pp. 59-72.

Guth, Hans P. The Literary Heritage, Toronto: D.C. Heath and Co, 1981.

Innes, C.L., "African Literature in English". Encyclopedia of Liteature and Criticism. Ed. Martin Coyle et.al., London: Routledge, 1990.

Iskarna, Tatang, Relasi antara Agama Kristen dan Kolonialisme dalam Tiga Karya Poskolonial Affrika. Disertasi. Yogyakarta: Universitas Gadjah Mada, 2018. 
Khapoya, Vincent B. The African Experience. London: Pearson Education, 2013.

King, Bruce, "New English Litarature" in Encyclopedia of Liteature and Criticism, Ed. Martin Coyle et.al., London: Routledge, 1990.

Kohn, Margaret. "Colonialism". The Stanford Encyclopedia of Philosophy (Summer Edition).

Edward N. Zalta (ed.), 12 August 201 http://plato.stanford.edu/archives/su m2012/entries/colonialism/>.

Loomba, Ania. Colonialism/Postcolonialism. London: Routledge, 2005.

Memmi, Albert. The Colonizer and The Colonized. Boston: Beacon Press, 1965.

Okon, Etim E., "Christian Mission and Colonial Rule in Africa: Objective and Contemporary Analysis". European Scientific Journal. Vol.10, No.14, 2014.

Said, Edward, Orientalism. New York, Vintage, 1978.

Schnabel, Eckhard J., Rasul Paulus Sang Misionaris: Perjalanan, Strategi, dan Metode Misi Paulus. Yogyakarta: Penerbit Andi, 2008.

Sidjabat, W.B. Panggilan Kita di Indonesia Dewasa Ini. Jakarta: Badan Penerbit Kristen, 1964.

Sugirtharajah, R.S. The Bible and the Third Word: Precolonial, Colonial, and Postcolonial Enconter. Cambridge: Cambridge University Press, 2004.

Thiessen, Henry C. Teologi Sistematika. Malang: Gandum Mas, 1997.

Thiong'o, Ngugi wa. The River Between. Chicago: Heinemann, 1965. 